Lucyna Dziaczkowska*

ORCID: 0000-0002-6387-8609

Lublin, Poland

\title{
Analysis of Selected Approaches to the Integral Pedagogy in Polish Pedagogical Thought
}

\section{Analiza wybranych ujęć pedagogiki integralnej w polskiej myśli pedagogicznej}

Summary: The article presented has attempted to analyse the selected approaches to integral pedagogy in Polish pedagogical thought. The rationale for the choices made by the author were personal declarations of practice, such as a type of pedagogy by specific researchers and/or classifying them as integral pedagogues by other pedagogues. The author provides arguments that the idea of integrity in pedagogy concerns researchers representing various trends in pedagogical thinking. At the same time, it is a subject of disputes conducted by them. The presentation of selected approaches of integral pedagogy by Sergiusz Hessen, Stefan Kunowski, Irena Wojnar, Bogdan Suchodolski, Marian Nowak, Zbigniew Kwieciński and Monika Jaworska-Witkowska, ends with a brief description of the position of Wiesław Andrukowicz, which is polemical towards their work.

Keywords: integral pedagogy; general pedagogy; personalistic pedagogy.

* Dr hab. Lucyna Dziaczkowska, professor of the Catholic University of Lublin, employee of the Department of Comparative Pedagogy and Philosophy of Education at the Institute of Pedagogy of the John Paul II Catholic University of Lublin. Address: Instytut Pedagogiki KUL, ul. Droga Męczenników Majdanka 70, 20-325 Lublin; e-mail: ldziaczkowska@kul.lublin.pl. 
Streszczenie: W prezentowanym artykule została podjęta próba analizy wybranych ujęć pedagogiki integralnej w polskiej myśli pedagogicznej. Uzasadnieniem dla dokonanych przez autorkę wyborów były osobiste deklaracje uprawiania takiej pedagogiki przez konkretnych badaczy oraz/lub zaklasyfikowanie ich przez innych pedagogów do grupy pedagogów integralnych. Autorka artykułu dostarcza argumentów, że idea integralności w pedagogice jest przedmiotem troski badaczy reprezentujących różne nurty myślenia pedagogicznego. Jest ona jednocześnie przedmiotem prowadzonych przez nich sporów. Prezentację wybranych ujęć pedagogiki integralnej autorstwa: Sergiusza Hessena, Stefana Kunowskiego, Ireny Wojnar, Bogdana Suchodolskiego, Mariana Nowaka, Zbigniewa Kwiecińskiego oraz Moniki Jaworskiej-Witkowskiej, kończy krótka charakterystyka polemicznego wobec ich twórczości stanowiska Wiesława Andrukowicza.

Słowa kluczowe: pedagogika integralna; pedagogika ogólna; pedagogika personalistyczna.

In modern Polish pedagogical thought, the terms 'integral upbringing' $(\text { wychowanie integralne })^{1}$, 'integral education' (edukacja integralna $)^{2}$ or 'integral pedagogy', as in the title of these considerations, are used quite often. It is difficult to talk about them selectively, although - as the title of this text suggests - the following analysis will focus on integral pedagogy, aiming at showing its diverse understanding in the work of Polish pedagogues. The category of integrity is common to all the afore-mentioned concepts. It should be understood as - in reference to the meaning of the Latin root (integralis - integral) - an inseparable connection of an element with the whole, but also as constituting entirety of all the various elements, and as totality (fullness), indivisibility and inviolability ${ }^{3}$. In light of this understanding, it seems redundant to describe pedagogy with such an additional adjective as 'integral'. It is, by definition, a branch of knowledge devoted to education ${ }^{4}$

1 Alina Rynio, „Integralne wychowanie”, in: Encyklopedia aksjologii pedagogicznej, eds. Krystyna Chałas, Adam Maj (Radom: POLWEN, 2016), 440-448.

${ }^{2}$ Wiesław Andrukowicz, Edukacja integralna (Kraków: Impuls, 2001).

${ }_{3}$ Słownik języka polskiego, ed. W. Doroszewski, https://sjp.pwn.pl/slowniki/integralno$\% \mathrm{C} 5 \% 9 \mathrm{~B} \% \mathrm{C} 4 \% 87 . \mathrm{html}$.

${ }^{4}$ In Polish pedagogy, hereby used term 'wychowanie' is understood by many pedagogues as an action directed towards supporting human development in all spheres of our personality and throughout all our life. 
choosing to study this phenomenon in its complexity and in its fullness. Unlike other sciences, it captures the reality of the participants in education in a holistic way - or in their sub-disciplines - aiming to explain and/or understand this reality, but always extracting an abstracted fragment of this object of cognition ${ }^{5}$.

\section{Integral pedagogy as general theory of education}

Before the outbreak of World War II, many Polish pedagogues were faithful to this understanding of pedagogy; however, very few managed to keep this faithfulness during the communist regime. One of the best-known pedagogues of the first group was Sergiusz Hessen (1887-1950) - a pedagogue of Russian origin, who in the final, significant and long (15 years) period of his life, joined the Polish pedagogical environment. The theory of education, outlined by him as a process of development with stratified character, has become one of the important impulses for the development of the theory of education by Stefan Kunowski (1909-1977) in the difficult (for freedom of creation and scientific research) post-war reality. Even the titles of writings crowning the work of both pedagogues suggest similarity of their scientific obligations (Podstawy pedagogiki [Basics of Pedagogy] by Hessen and Podstawy wspótczesnej pedagogiki [Basics of Contemporary Pedagogy] by Kunowski) ${ }^{6}$.

Kunowski expanded the list of so-called strata of education. He included in this group the biological, the psychological, the sociological, the cultural and the worldview-related strata ${ }^{7}$. Meanwhile, Hessen mentioned the following layers: the biological, social existence-related, spiritual culture-related and moral community-related ${ }^{8}$. Kunowski has also indicated and described

${ }^{5}$ Kazimierz Sośnicki, Istota i cele wychowania (Warszawa: Nasza Księgarnia, 1967), 26-27; Dariusz Kubinowski, „Pedagogiczne myślenie humanistyczne jako kategoria metodologiczna”, in: Metodologia pedagogiki zorientowanej humanistycznie, eds. Dariusz Kubinowski, Marian Nowak (Kraków: Impuls, 2006), 178.

${ }^{6}$ For the convenience of the reader the titles are given always in Polish, followed by the English translation, even if the publications not always were translated into English.

7 Stefan Kunowski, Podstawy wspótczesnej pedagogiki (Łódź: Wydawnictwo Salezjańskie, 1981), 215-238.

${ }^{8}$ Sergiusz Hessen, O sprzecznościach i jedności wychowania (Warszawa: Wydawnictwo „Żak”, 1997), 160-178. 
the dynamics of education. These are the forces that actively create the process of 'educational development': bios (the power of biological development), ethos (the power of social custom), agos (the force of conscious parenting directed to a certain ideal of a 'new man') and fate (the power that connects destiny factors in the form of events independent of the individual, with vocational factors that define human uniqueness and allow a person to respond to them freely and creatively) ${ }^{9}$.

Both Hessen and Kunowski regarded education as a life-long process, covering the whole person (all spheres of their existence and activity). They formulated the laws regulating this process, showing its logic and dynamics. Their work was focused on developing the general theory of education. Kunowski explicitly emphasised that the general theory of education is the key task and effect of general pedagogy, also referred to as theoretical pedagogy by this author ${ }^{10}$. Thus, the main attribute of integral pedagogy - the concern for showing the complexity and fullness of educational reality - is attributed by Kunowski to general (theoretical) pedagogy.

The postulate to create general pedagogy as integral pedagogy was also formulated in the recent past, after the systemic transformation in Poland (in 1989), by Irena Wojnar. Seeing an example of realising this postulate in the works of Bogdan Suchodolski (1903-1992), and inspired by this source, the author lined out the essential properties of general pedagogy as the one that directs its efforts to seek ways of shaping human personality, "having its roots in the great philosophical ideas of Greek antiquity" and currently developing in various "currents of European thought", but above all relying on "humanistic values"11.

Making further reference to the concept of integral pedagogy by Bogdan Suchodolski, formulated in a monograph published in 1983: Wychowanie i strategia życia [Education and Strategy of Life], Wojnar indicates that the main task of the integral pedagogy would be to combine "personality shaping with preparation for life", "development of 'the human wealth' of existence" 12 . She also draws attention to the ideal of upbringing the "integral human", present in the work of Suchodolski, which requires focusing of ed-

\footnotetext{
${ }^{9}$ Kunowski, Podstawy, 191-201.

${ }^{10}$ Ibidem, 37.

${ }^{11}$ Irena Wojnar, „Jedność i różnorodność pedagogiki zwanej ogólną”, in: Rozwój pedagogiki ogólnej. Inspiracje i ograniczenia kulturowe oraz poznawcze, ed. Andrzej Bogaj (Warszawa-Kielce: Wydawnictwo Instytutu Badań Edukacyjnych, 2001), 40.

12 Ibidem, 41.
} 
ucational processes on the "fullness of humanity", taking into account the "diverse richness of human nature, the even development of all personality elements" primarily through "stimulating creativity and ability to shaping one's own person" ${ }^{13}$. In the light of Suchodolski's concept, integrity taken as a goal of education towards the fullness of humanity includes the physical, mental, emotional or ethical integrity of every human being, but also assumes "integration of the individual with the cultural, social and economic life of a specific community, and thus the preparation of human reserves for its enrichment" ". Pointing to the broad "problem horizon" that integral pedagogy requires "human - world" and its broadly defined dimensions, "past present - future", as well as its "guiding idea" - "humanism that guarantees the value of the human person", Irena Wojnar raises the question of whether - in the face of "the current condition of the world and man", we are not dealing here with "the tragic humanism"15.

This pathos, tensions and dilemmas of the human condition simultaneous to the need for educational preparation of people for the future, have been repeatedly emphasised by Suchodolski in his work. It may seem that the position of this pedagogue was very close to the personalistic approach to education, in which - as will be discussed later - the postulate of the holistic view of man - the participant and the originator of this phenomenon - is formulated. Suchodolski himself did not make such declarations, locating himself (or being located) in the so-called secular humanism. On the other hand, his critical statements about the very philosophy of personalism are known, e.g.:

Personalism [...] is an attempt to defend man against the world, it is an attempt to create his own kingdom beyond a concrete, everyday reality, to transfer him into religious perspectives, into an automatically understood world culture or, finally, inner loneliness protected from the hustle and bustle of life [...], the foundations of personalism in its various types can be described as the philosophy of a man without the world. Man becomes an autonomous, metaphysical being in it and saves himself, the only and unique at the price of departing from the concrete reality in which he lives, abandoning the risk and responsibility associated with the place and time of his existence ${ }^{16}$.

13 Ibidem, 41.

14 Ibidem, 41-42.

15 Ibidem, 46.

${ }^{16}$ Bogdan Suchodolski, Świat człowieka a wychowanie (Warszawa: Książka i Wiedza, 1967), 109. 
The analysis of the quoted statement shows that Suchodolski accused the "different types" of personalism of escaping from the world, alienating reflection on the personality of man from the living socio-cultural context, and setting the perspective of human activity and development on the religious ground. He himself emphasised that

the personality problem concerns mainly the place and the role of man in the social world [...], it is today a problem of social planning and individual promotion, the problem of conflicts between opportunist adaptation to living conditions and a bold attempt to transform them, [...] a problem of responsibility for one's own fate and for engaging in common issues ${ }^{17}$.

Therefore, Suchodolski's reading of personalism is very critical and, at the same time, inconsistent with the aspirations and declarations of its representatives ${ }^{18}$, stressing the need for philosophical reflection of the fullness of humanity; this is also built in the spiritual dimension, but does not refer only to the human culture, but also to the Absolute ${ }^{19}$. Therefore, it is not compatible with the personalistic view of man and education on the ground of pedagogy. At the same time, one should be aware of the fact that the very concept of personalism has been used in the past and currently by theoreticians, including pedagogues, who are building more than one of its types.

What is more, the above approach was mirrored by some of the representatives of the classical pedagogy of culture, even previously mentioned Sergiusz Hessen, who provided his work $O$ sprzecznościach i jedności wychowania [On the Contradictions and Unity of Education] with a subtitle: Zagadnienia pedagogiki personalistycznej [Problems of Personalistic Pedagogy], indicating in his works the aim of education, which is "turning temperament into personality". In doing so, he placed the achievement of the personality structure as the crowning of educational efforts, above all the creative effort of the educated person ${ }^{20}$.

17 Ibidem, 110.

18 Jacques Maritain, Humanizm integralny (Warszawa: Wydawnictwo Krąg, 1981), 6.

19 Katarzyna Jasińska, „Bogdana Suchodolskiego personalizm laicki?”, in: Wychowanie na rozdrożu. Personalistyczna filozofia wychowania, ed. Franciszek Adamski (Kraków: Wydawnictwo Uniwersytetu Jagiellońskiego, 1999), 231-236.

${ }^{20}$ Sergiusz Hessen, Podstawy pedagogiki (Warszawa: Wydawnictwo „Żak”, 1997), 109-113. 


\section{Integral pedagogy in Christian inspiration}

These days, the concept of personalism usually is delved into in Polish pedagogy in the works of representatives associated with the Christian approach to humanity and education. The works of pedagogues of this current are sometimes associated with confessional literature, addressed to members of a particular religious community. However, such affiliation is not fully justified for, in its essence, this pedagogy formulates the postulate of encompassing all areas of personal existence and activity of a person participating in educational processes. It calls for not silencing, not pushing any of these spheres into the taboo zone.

Meanwhile, in the Polish pedagogy created during the reign of socialism, the sphere of religious and spiritual life constituted such a zone. If the reflection on it appeared in the work of Polish pedagogues, it usually concerned depreciating the value of this area of human existence. One of the few exceptions that went against this tendency was the stratified theory of education by Stefan Kunowski. Pointing to the need to diversify the educational support of biological, psychological, social and cultural development, along finally the development of the stratum of worldview in the personal existence and activity, Kunowski explains the dynamics of the latter,

The fifth layer, purely spiritual, develops under the influence of a separate form of human activity, which becomes a deeper experience concerning worldview. In this experience the fullness of the emerging human spirituality and the openness to transcendent and metaphysical issues is voiced. Cognitive and teleological questions arising from the nature of a wise man begin to reach the problems of the sources of being, its beginning and end, the origin and purpose of the world and life. Thanks to this, the synthesis of a personal worldview develops, in which the source of being as a philosophical absolute will be included in the shape given by the main idea of one's life, developed creatively by the individual. It can be [...] the idea of the fight, the work or a hedonistic idea [...], or a heroic idea of love. Therefore, on the purely spiritual level, a certain type of worldview is shaped, e.g. the positivist one (struggle for existence and enrichment), the socialist one (revolutionary struggle and productive work), the liberal one (scientific and cultural creativity), the Christian one (love of God and neighbour) or the common materialism of life (luxury and relaxation) ${ }^{21}$.

${ }^{21}$ Kunowski, Podstawy, 236-237. 
It is clear from the quoted text that Kunowski does not pursue the creation of a confessional concept of education but builds the basis for a universal, a-ideological theory.

Showing the education as a complex and a life-long process, Kunowski analyses the above-mentioned strata, as well as its diverse forces (dynamisms) determining its effects: bios - the strength of biological development, ethos - the strength of social custom, agos - the power of pedagogical action and fate linking destiny factors - independent of man, and vocational factors through which man can express his freedom and creativity ${ }^{22}$. The theory of education formulated by Kunowski captures this process in its multi-aspectivity as an action inscribed in the pursuit of the fullness of humanity. This theory becomes an example of a universal approach to educational reality, not imposing any ideological muzzle. His analysis of the Christian function of education (christianisare) allow Kunowski to be seen as the creator of the Christian concept of education, in the framework of which the author shows the need and possibility of permeating all other educational functions with references to the Person of Christ.

However, similar assumptions marked by their own creative and original research achievements - sometimes including elements of criticism of Kunowski's theory - can be read in the works of other contemporary active representatives of the personalistic thought in Polish pedagogy. A comprehensive monograph by Marian Nowak, Podstawy pedagogiki otwartej [Fundamentals of Open Pedagogy], whose title announces a universalist, general approach to research of educational reality, can be considered as the most representative example of such a study. On the other hand, the subtitle, Ujęcie dynamiczne w inspiracji chrześcijańskiej [Dynamic Approach in Christian Inspiration], already points to the perspective in which education is finally shown by the author.

At the same time, the author draws attention to the anti-ideological character of the personalistic approach to the study of human reality. On this occasion, he refers to the work of Jean Lacroix and his Le personalisme comme anti-idéologie [Personalism as Anti-ideology]. Referring to this source and to the work of other personalistic thinkers (Polish - Wincenty Granat, Janusz Tarnowski and Italian - Armando Rigobello), he writes that personalism is

"a fighting thinking", which is practice-oriented and "committed philosophically and politically". [This thinking is] about defending man from such an ideo-

${ }^{22}$ Ibidem, 278. 
logical organisation of life that could lead to killing and trampling the dignity of the human person. It is thinking fighting against the pursuit of such organization of social and political life, in which there would be no room for the person and community of persons, for interpersonal relations, for authentic "interpersonal dialogue"23.

By recognising such thinking - promoting the priority and value of the human person - Nowak indicates that it generates a "moral obligation", as an obligation to commit to the person. For pedagogy, such a commitment means the need and "the necessity to show all manifestations of one-sidedness and threats that may occur for the human person in the process of education" 24 . Furthermore, "The basic pedagogical option going in this direction is to advocate for variety and diversity of forms of life and education. All kinds of one-sidedness and too superficial generalisations should be the subject of 'critique of ideology' in pedagogy" 25 .

The author quoted himself undertakes the search for "an integral and open approach to education". Referring to Jacques Maritain's Integral Humanism, he explains the essence of such an approach: "It should, without blurring the multi-faceted connection of man with the natural world, recognise the transcendent dimension of man and his relationship with God as well. In contrast, therefore to biological, social, cultural and ideological approaches, this should be an approach that transcends partial and one-dimensional perspectives"26. In further explanation of this position, the author indicates that this approach should reflect a real, multi-dimensional image of education in its various aspects as "living, cognitive, psychological, ethical and, above all, existential". Representing a position similar to "multidimensional realism", this approach also opens up to the theological perspective which, in a particular way, specific for itself, can explain the fact of education ${ }^{27}$.

Taking into account this perspective, Marian Nowak creates his proposition of "open pedagogy" constructed "in Christian inspiration". Aiming to formulate its basis, he makes a critical analysis of the main concepts of education and its essence. He emphasises the value and significance of those

${ }^{23}$ Marian Nowak, Podstawy pedagogiki otwartej. Ujęcie dynamiczne w inspiracji chrześcijańskiej (Lublin: RW KUL, 1999), 221-222.

${ }^{24}$ Ibidem, 222.

${ }^{25}$ Ibidem.

${ }^{26}$ Ibidem, 269.

27 Ibidem, 269-270. 
concepts that are aimed at the realistic approach to education and its possibilities. Thus, these foundations do not fit with the "pedagogical pessimism" (which assumes that the educated subject does not need any external educational help, being that his "inner strength" suffices because he is equipped with everything that will enable him to develop himself), or in "pedagogical optimism" (assuming that the power of education is almost omnipotent and therefore external factors in the form of educators themselves and appropriately selected educational measures, will guarantee educational success ${ }^{28}$. The basics of open pedagogy can only be built on the basis of "pedagogical realism", which requires the pedagogue to adopt a "realistic attitude" that takes into account the specific human being together with the external conditions surrounding and affecting him ${ }^{29}$.

Making a specific introduction to his original concept of upbringing, Marian Nowak analyses and explains basic pedagogical concepts important for the following deliberations: formation and education. The distinction between them is important for the assumptions of the Christian approach to the essence, the tasks, the structure and the possibilities of education. He indicates that the formation (also in the foreign languages' equivalents such as German - die Bildung, or Russian - obrazovanije) refers to the biblical image of a man created "in the image of God and His likeness" (Gen 1: 26-27). It signifies the process of man's becoming similar to God's image (Imago Dei) and the effort he made for such a purpose. Although the concept of formation has undergone transformations, which Nowak writes extensively about, in its modern meanings it kept important elements of biblical connotations.

The representatives of Christian thought refer to it in a manner faithful to this original meaning. Amongst them, Marian Nowak has distinguished Romano Guardini (1885-1968) - an outstanding theologian, philosopher, and also psychologist and pedagogue. As Nowak writes, this world-known Christian thinker perceives the basis of pedagogy in the category of "image" (das Bild) and "Imago Dei", defining the Christian understanding of formation and indicates its essence in "auto-formation" (Die Selbstbildung) ${ }^{30}$. Formation takes place on the basis of the reference of a specific human person to their "internal image" which, for a Christian, is a gift inscribed in them "by the creative and legislative will of God Himself". This image gains a sense analogous to the Orthodox icon where the message contained in the

\footnotetext{
${ }^{28}$ Ibidem, 280-281.

29 Ibidem, 282.

${ }^{30}$ Ibidem, 285.
} 
"mystery of the icon" intends to show the "real dimension of existence" of a person, not some fiction or phenomenon ${ }^{31}$.

Such a formation is ultimately translated into auto-formation and has, therefore, an internal character. Nevertheless, it requires external help because "no man knows by himself, what is the essential order of the world (the essence of human existence). To be able to shape it, he needs a second person, the other 'I' that would become his 'you" "32. This external, social help in auto-formation, requiring the presence of other people and their activities, gains in the presented approach the name of education. Formation and education, although essentially different, are inseparable from each other, which is best reflected in the conclusion formulated by Nowak, "There is no formation without the necessary help, which is 'education', nor does there exist 'education' that would not be oriented to formation" and by the theologian and Catholic pedagogue Johann Michael Sailer, quoted by him: "Any education is an aid in achieving the goal of formation"33.

Analysing the views of the representatives of Christian thought in relation to education, Nowak is looking for those views that take it in the most open, realistic way, those in which one can find "an important sense of educational activity in the Christian understanding". Referring to the thought of Marguerite Léna - a French thinker who deals with the philosophy of education - he exposes this approach to education in which it is understood as "the totality of ways and processes taking place through interaction [...] helping the human person in realising themselves by opening themselves to what is beyond them - for good, truth and beauty. In this way, the human person begins to realise them, striving for them from the lowest values, through the spiritual to the absolute, directed towards God in Christ" 34 .

The need to take into account the religious and spiritual perspective of education comes from the fact that the human person in their existence "transcends the visible world of matter". Taking into account this perspective thus confirms the aspiration of the pedagogue adopting it to "the integral and realistic approach to education" 35 . The quoted author himself makes the effort resulting from with this approach by seeking ontological, anthropological and axiological foundations of "open pedagogy" and analysing the educa-

\footnotetext{
31 Ibidem, 285.

32 Ibidem, 286.

33 Ibidem, 286-287.

34 Ibidem, 289.

35 Ibidem, 293.
} 
tional relationship in its three basic aspects (the subject of education, educator and educational situation). The culmination of this search is to show "the possibilities and role of Christian inspiration, for current research in general pedagogy" read in the context of "contemporary pedagogical problems"

\section{Integral pedagogy in terms of critical theory of education}

The presence of significant assumptions of integral pedagogy and, above all, the one that requires the holistic view of a human participant of educational processes and holistic approach to these processes can also be found in the work of Polish pedagogues referring to the views of the critical theory of education. The most eloquent example of this is Zbigniew Kwieciński's text, entitled Dziesięciościan edukacji (sktadniki i aspekty - potrzeba catościowego ujecia) [The Decahedron of Education (Components and Aspects - The Need for a Holistic View)], which is a fragment of the monograph, known not only in Poland under the following title Socjopatologia edukacji [Sociopathology of Education]. Although the author himself does not use the tag of "integral pedagogy" to designate his work but "the need for a holistic view" of the components and aspects of education communicated in the indicated text, it informs the reader about the researcher's effort to meet the requirements of this type of pedagogy.

The approach to education proposed by Kwieciński is an attempt to organise its elements according to the criterion of "content range of the object, goals, processes and effects of education, starting from the global problems of the world, and ending with the generic dimension of human as an organism" ${ }^{37}$. Understood in that way, education consists of 10 component processes: 1) globalisation understood as education sensitising to world-wide problems; 2) etatisation, i.e. education preparing to participation in the life of the state; 3 ) nationalization, that is education addressing the issues of cultural specificity of the nation, its traditions ties and separateness; 4) ectypal socialisation (collectivisation) understood as shaping the ethos of solidarity amongst people of similar social position, shaping beliefs about a special place and mission of their own social class; 5) politicisation, bureaucrati-

36 Ibidem, 74.

37 Zbigniew Kwieciński, Socjopatologia edukacji (Olecko: Mazurska Wszechnica Nauczycielska, 1995), 14. 
sation and professionalisation - educational processes preparing for life "in organisational and institutional world", and "education for work and profession"; 6) primary socialisation - including educational processes taking place in primary groups (family, peer group, local community); 7) enculturation and personalisation understood as acquisition of cultural identity, combined with preparation for autonomous life choices; 8) upbringing and juridification, or "introduction to implement and accept civic roles and activities" and "shaping legal awareness"; 9) education and humanisation understood as personal development of a person, approximate to "dignity values", as well as gaining a mature worldview; 10) hominisation, or "shaping the generic traits of a human", included in health education, preparing the individual to acquire personal "gratification without harming others", and "channel primary needs" ${ }^{\prime 3}$.

Presenting this proposal of a comprehensive approach to educational processes, Zbigniew Kwieciński has sensitised the pedagogues to the fact that in the course of their implementation, there may be two undesirable disturbances (due to the dynamics of the development of the individual and the society). The first type concerns excess - unwanted surfeit - of activities related to a specific process. The second is associated with a shortage or lack of educational activity in a specific scope. For example, the hypertrophy of globalisation activities in education may lead to shaping globalisation attitudes, and their shortage to pathological particularism, and to being closed to the needs of humanity on a global scale ${ }^{39}$.

Zbigniew Kwieciński's attempt at a comprehensive approach to education was highly appreciated by Polish pedagogues and it may be said that it has fulfilled the author's expectations by creating a "network of concepts that can be used to analyse conflicts, 'collisions' (as K. Sośnicki used to say) of specific pairs (or many simultaneous) processes that constitute education, including the conflict of excesses or shortages of etatisation and socialization, as well as and conflicts between etatisation and inculturation, personalisation and humanisation" 40 . The approach to educational processes proposed by Kwieciński has thus become a tool for analysing educational reality, which is readily used in Polish pedagogy.

One original example of such practice of pedagogy can be the work of Monika Jaworska-Witkowska. In the monograph entitled $W$ strone pedagogi-

\footnotetext{
38 Ibidem, 14-15.

39 Ibidem, 15-17.

${ }^{40}$ Ibidem, 18.
} 
ki integralnej. Peregrynacje humanistyczne [Towards Integral Pedagogy. Humanistic Peregrinations], the author attempts to take "new ideas and clues for general didactics" from other (than pedagogy) fields of the contemporary humanities ${ }^{41}$.

The afore-mentioned work clearly refers to another monograph on the part of this author, co-written with Lech Witkowski, Przeżycie - Przebudzenie - Przemiana. Inicjacyjne dynamizmy egzystencjalne w prozie Hermana Hessego (tropy i kategorie pedagogiczne) [Experience - Awakening Transformation. Initiative Existential Dynamisms in Herman Hesse's Prose (Pedagogical Hints and Categories)] - and can be treated as a kind of its continuation. Although Jaworska-Witkowska herself points out that the intentions of both works were different, the latter, according to the declared aim, was to "show the themes of Hesse's prose as a model and background for further pedagogical research". The one that in its title emphasises the heading towards integral pedagogy served to "formulate, present and partially implement a broader research program regarding searching the literature, psychoanalysis, religious studies, mythology, philosophy and economics as life-giving educational 'nether world'". The area of Jaworska-Witkowska's research is, apart from Hesse prose, the depth psychology of Carl Gustav Jung. The work of these two authors becomes the material serving to seek an answer to the question contained in the title of the preface to the monograph, "What Is the Whole Man Silent About?"

The content of the above question and the motto adopted for the Preface eloquently explain the way of problematisation of the issue of the fullness of humanity, its integrity or the integrity of culture and education as processes in which a person enters or is, more or less deliberately, entangled. Let us quote, therefore, the motto adopted by Jaworska-Witkowska. It comes from the philosophical essay of Jolanta Brach-Czaina, Szczeliny istnienia [The Cracks in Existence":

I think, when philosophers speak with despair about the silence of being, it results from a misunderstanding of the speech of being that does not address us as a whole, but through an existential concrete, significant particles. It is true that they are able to suggest the voice of the whole, but always ringing in the particles of existence. And it is worth sticking to this trail [...], even if we were

${ }^{41}$ Monika Jaworska-Witkowska, W strone pedagogiki integralnej (Szczecin: Wydawnictwo Naukowe Uniwersytetu Szczecińskiego, 2007). 
only interested in how "something" that exists, breaks the silence of being and appeals to our understanding ${ }^{42}$.

The aims of learning and creating pedagogy which are characteristic for the critical theory of education resound in the manner of understanding of integrity by the cited author. Formulating the aim guiding her when writing a monograph $W$ strone pedagogiki integralnej [In the Direction of Integral Pedagogy], she describes it as

facilitating vocabulary, ideas, generative metaphors of methodological behaviour, such as development as the inevitable breakdown of the surrounding world structure, the category of shadow as the lost dimension of the world and individual existence or symbolic death as a phenomenon restoring the value to life through understanding and acceptance of its life-giving tragedy. [...]. W strone pedagogiki integralnej aims at new systematization of an old material and the simplification of such "matrices" for further efforts of "pedagogical" reading, facilitating searching of the nether world of the humanities ${ }^{43}$.

In the first chapter entitled Pedagogika ( $z$ wnętrza) kultury i nowa paideia [Pedagogy (From the Inside) of Culture and the New Paideia], the author announces the presentation of the assumptions of the research project "situated at the intersection of general didactics, depth psychology, psychoanalysis, philosophy of education, literature, literary studies, religious studies and pedagogy of culture" 44 . As she explains, this procedure is to facilitate the search for paths of "development of the whole, full man" and "vision of culture seen as paideia" ${ }^{45}$.

Choosing i.al. the depth psychology of Carl Gustav Jung as a space to draw inspiration from for the implementation of the above objectives, the author expresses her position on the condition/attitude of contemporary pedagogy to the measures that she herself undertakes:

Pedagogy still fears allegedly "non-pedagogical" (and even non-academic) "furious ideas", "bizarre categories" cultivated in "a dangerous paradigm". The source of this panic may be the difficulty in breaking through the threads of

\footnotetext{
${ }^{42}$ Ibidem, 9.

43 Ibidem, 18-19.

${ }^{44}$ Ibidem, 31.

45 Ibidem, 35.
} 
contemporary humanities to the psycho-pedagogical reception. If I would like to ironically express this state of pedagogical (self)consciousness, I would borrow the voice of Emil Cioran: "the worst diligently expected" [...] because pedagogy as a science of (whole) man cannot afford to impoverish and arbitrarily eliminate from his discourse the worst - urgent - anticipated concepts and categories ${ }^{46}$.

By rejecting such fears regarding the works of Hesse and Jung, Jaworska-Witkowska seeks in their work certain diagnoses of human possibilities and limitations, as well as inspirations that help to construct projects of pedagogical emancipation. When assessing the suitability of Jung's works for the implementation of such goals, the author writes:

Jung made attempts to construct a teleological/telocentric perspective on human development, and underlining the finalistic model of the development process, assuming the existence of a hidden program within the structure of the psyche (hidden mind, hidden memory), might constitute an appeal instance for the design of development, emancipation and expansion of the fields of external and internal freedom, despite the recognition of the primacy of unconscious structures $^{47}$.

The use of Hesse's and Jung's writings by Jaworska-Witkowska in her works is treated by her as an important way of implementing the postulate of integrity. In a later monograph, she will distinguish the types of understanding integrity in pedagogy, pointing to its "traditional versions" such as: 1) didactic understanding - meaning the implementation of the postulate of "coupling the content, forms and objects of education into a holistic mode of connection, $[\ldots]$ so that the whole of the subject reference, $[\ldots]$ was not a hostage of rigid frames and divisions, $[\ldots]$ detrimental, $[\ldots]$ separating from each other and depriving them of the ability to see and use ties and mutual interactions"; 2) "the idea of 'versatility' of education and comprehensive human development"; 3) the postulate of "interdisciplinarity", the implementation of which assumes that "autonomous entities, being fully competent in their scope provide each other with the fruits of their investigations"; 4) implementation of the postulates of "intercultural" pedagogy - "here integrity opposes [...] the power of universalist claims and pressure on domination"; 5) the methodological postulate of holism, close to the author - i.e. "learning

\footnotetext{
46 Ibidem, 54.

${ }^{47}$ Ibidem, 55.
} 
the whole as irreducible to its components"48. Jaworska-Witkowska complements this list of "traditional versions of integrity" with the postulate that she is trying to pursue in her work - "to restore and further develop the vision of its tasks and chances in the context of recreating ties and inspirations present in the wider field of the humanities than usually prevails"49.

\section{Conclusions}

The afore-mentioned examples of creation of the integral pedagogy prove that, in Poland, the concept has been created by representatives of various trends in pedagogical thinking. With this in mind, it can be said that on the basis of Polish pedagogy there is a discussion about the implementation of the postulate of an integral approach to educational reality and its participants. What unites the representatives of the diverse positions in this field is a joint commitment to undertake a difficult and even impossible to be fully completed task; a holistic view of the educational reality and grasping the full personal existence and action of its participants on the background of this reality.

The image of Polish integral pedagogy is not only diverse but also dynamic. In conclusion, it is also worth mentioning that from among its representatives its critics have also emerged. One of them is a didactic, Wiesław Andrukowicz. He is the author of a monograph entitled Edukacja integralna $[\text { Integral Education }]^{50}$. However, he has abandoned the category of integrity in favour of "complementarity", considering "irrelevant" the terms associated with the former: "integral education" or "integral development and education", accepting the argument that they cannot "contain their negation, which sometimes has greater meaning [...] than the pursuit of integration". Starting from this assumption, the author decided that the category of complementarity is more capacious and within the study one can tell "about positive and negative integration and the same disintegration" ${ }^{51}$. Regardless of agreeing/ disagreeing with him, the critical voice of the former supporter of integral

48 Monika Jaworska-Witkowska, Ku kulturowej koncepcji pedagogiki. Fragmenty i ogarnięcie (Kraków: Impuls, 2009), 61-63.

49 Ibidem, 71.

${ }^{50}$ Andrukowicz, Edukacja integralna.

51 Wiesław Andrukowicz, By dziecko było geniuszem. Wprowadzenie do edukacji komplementarnej (Kraków: Impuls, 2011), 16. 
pedagogy sensitises its representatives - to the traps of these practices. The most dangerous amongst them is the one that the integral pedagogy itself warns about - the trap of the reduction of humanity. This is the recognition of the participant of educational reality, which pushes out from pedagogue's perspective the realistically existing areas of his personal existence, his needs and abilities, and does not make them a subject of an educational concern for the fullest possible personal development.

Translated by Magdalena Dziaczkowska

\section{References}

Andrukowicz, Wiesław. By dziecko byto geniuszem. Wprowadzenie do edukacji komplementarnej. Kraków: Impuls, 2011.

Andrukowicz, Wiesław. Edukacja integralna. Kraków: Impuls, 2001.

Hessen, Sergiusz. O sprzecznościach i jedności wychowania. Zagadnienia pedagogiki personalistycznej. Warszawa: Wydawnictwo „Żak”, 1997.

Hessen, Sergiusz. Podstawy pedagogiki. Tłum. A. Zieleńczyk. Warszawa: Wydawnictwo „Żak”, 1997.

Jasińska, Katarzyna. „Bogdana Suchodolskiego personalizm laicki?”. In: Wychowanie na rozdrożu. Personalistyczna filozofia wychowania, ed. Franciszek Adamski, 229-243. Kraków: Wydawnictwo Uniwersytetu Jagiellońskiego, 1999.

Jaworska-Witkowska, Monika. Ku kulturowej koncepcji pedagogiki. Kraków: Impuls, 2009.

Jaworska-Witkowska, Monika. W stronę pedagogiki integralnej. Szczecin: Wydawnictwo Naukowe Uniwersytetu Szczecińskiego, 2007.

Kubinowski, Dariusz. „Pedagogiczne myślenie humanistyczne jako kategoria metodologiczna". In: Metodologia pedagogiki zorientowanej humanistycznie, eds. Dariusz Kubinowski, Marian Nowak, 171-187. Kraków: Impuls, 2006.

Kunowski, Stefan. Podstawy współczesnej pedagogiki. Łódź: Wydawnictwo Salezjańskie, 1980.

Kwieciński, Zbigniew. Socjopatologia edukacji. Olecko: Mazurska Wszechnica Nauczycielska, 1995.

Maritain, Jacques. Humanizm integralny. Warszawa: Wydawnictwo „Krąg”, 1981.

Nowak, Marian. „Metodologia pedagogiki między «naukowością/teoretycznością» a «praktycznością»". In: Metodologia pedagogiki zorientowanej humanistycznie, eds. Dariusz Kubinowski, Marian Nowak, 145-170. Kraków: Impuls, 2006. 
Nowak, Marian. Podstawy pedagogiki otwartej. Ujęcie dynamiczne w inspiracji chrześcijańskiej. Lublin: RW KUL, 1999.

Rynio, Alina. „Integralne wychowanie”. In: Encyklopedia aksjologii pedagogicznej, eds. Krystyna Chałas, Adam Maj, 440-448. Radom: POLWEN, 2016.

Sośnicki, Kazimierz. Istota i cele wychowania. Warszawa: Nasza Księgarnia, 1967.

Suchodolski, Bogdan. Świat człowieka a wychowanie. Warszawa: Książka i Wiedza, 1967.

Wojnar, Irena. ,Jedność i różnorodność pedagogiki zwanej ogólną”. In: Rozwój pedagogiki ogólnej. Inspiracje i ograniczenia kulturowe oraz poznawcze, ed. Andrzej Bogaj, 39-47. Warszawa-Kielce: Wydawnictwo Instytutu Badań Edukacyjnych, 2001. 
